\title{
Espetáculos da diferença: a Exposição Antropológica Brasileira de 1882
}

\author{
Jens Andermann
}

\section{Grande abertura}

A data é 29 de julho de 1882. Os fogos de artifício, acompanhados pela música das bandas militares, iluminam o céu da cidade do Rio de Janeiro comemorando o aniversário da princesa Isabel: um feriado nacional festejado em todo o Império do Brasil. ${ }^{1}$ A própria princesa é a convidada de honra de mais um portentoso evento da temporada, promovido pelo Museu Nacional no Campo de Sant'Anna, contando com a presença dos mais ilustres membros da sociedade carioca. O imperador D. Pedro II, reconhecido pelo seu grande entusiasmo na promoção das artes e das ciências, está também presente com a sua esposa, a imperatriz Teresa Cristina, ao lado de alguns dos mais notáveis bacharéis do império que haviam doado objetos ou contribuíram com algum texto no número especial da $R e-$ vista Illustrada que, editada por Mello Moraes Filho, será distribuída ao publico no transcurso do evento. O catálogo da exposição, também ainda em fase de preparação, contará com 70 páginas enumerando os objetos da amostra, a qual se estende pelos oito salóes do primeiro andar do museu. Redecorados especialmente para a ocasião, cada salão recebeu o nome de algum famoso etnógrafo e naturalista do passado, dos cronistas portugueses Pedro Vaz de Caminha e Rodrigues Ferreira aos missionários dos séculos XVI e XVII Gabriel Soares, José de Anchieta e Jean de Léry, incluindo ainda os cientistas contemporâneos como Martius, Hartt e Lund. Para noticiar o evento ao grande público, a ocasião conta com a presença de jornalistas dos principais periódicos da cidade, entre eles o famoso (e também temido) caricaturista Angelo Agostini e o fotógrafo Marc Ferrez. Finalmente, assiste ao evento um pequeno grupo de índios Botocudo provenientes do Espírito Santo e outros três índios da tribo Xerente de Minas 
Gerais, trazidos para a capital do império para permanecer no museu durante o período da exibição. Em seu discurso de abertura, Ladislau Netto, o diretor do museu, endereça-se à multifacetada audiência presente com as seguintes palavras:

Este é o certame mais nacional que as ciências e as letras poderiam, congratuladas, imaginar e realizar no fito de sorguer o império do Brasil ao nível da intelectualidade universal [...] E esse grandioso remate de nossos trabalhos, e esse almejado fim de nossas aspiraçōes, e consenso público, o apôio das sociedades sábias e a mal contida surpresa de quantos aqui se acham, estão a testificar ser o grande jubileu de Antropologia brasileira que hoje se inaugura neste Museu. (Netto em Duarte, 1960: 167-9).

A Exposição Antropológica Brasileira, cuja cerimônia de inauguração nos empenhamos em reconstruir nestas linhas, foi, antes de mais nada, uma tentativa do Museu Nacional em recuperar sua antes exclusiva autoridade para expor os objetos representantes do patrimônio nacional, frente a um número crescente de rivais: além das exposiçôes nacionais e estaduais organizadas com regularidade desde 1861, a fim de eleger o material a ser exposto nas grandes feiras mundiais, as Exposições de Belas Artes celebradas pela Academia Imperial e as Exposições Horticulturais que se repetiam anualmente desde 1879 na réplica do Crystal Palace construído pelo Conde D'Eu - marido da princesa Isabel - em Petrópolis; ainda concorrendo com o Museu Nacional estavam a Biblioteca Nacional que em 1881, ano anterior à Exposição Antropológica Brasileira, havia organizado a primeira exposição em grande escala sobre a história do Brasil, e a Exposição Nacional das Indústrias em preparação à Exposição Continental de Buenos Aires, realizada na Secretaria de Agricultura. Se, segundo Walter Benjamin (1983), a luta contra a dispersão é a força secreta que motiva o colecionador, a Exposição Antropológica ocupava um lugar crucial neste "complexo expositório" do segundo reinado, já que a sua maior preocupação era a de resgatar e revalorizar a iconografia indianista do Império que na época parecia ter se tornado redundante. Porém, como veremos a seguir, mais do que uma celebração da riqueza e diversidade das comunidades indígenas brasileiras, tanto passadas quanto presentes, com seus artesanatos e símbolos, o evento se destinava à "celebração popular da ciência" conforme ha- 
via afirmado o fisiologista e futuro diretor do museu, João Baptista de Lacerda. Lacerda se referia à celebração da antropologia como conquista de uma perspectiva imparcial e "objetiva" sobre um Outro interno que havia até então fornecido ao Estado monárquico um dos seus principais ícones artísticos e literários. A evidência material da "realidade" da vida indígena exigia uma reavaliação da utilidade do índio como representante da nação moderna. Ao mesmo tempo, como irei expor no decorrer do presente ensaio, a re-enunciação científica do índio enquanto vida nua (bare life) usando aqui o conceito de Giorgio Agamben (1998) que iremos discutir mais detalhadamente a seguir -, numa dialética complexa de exclusão inclusiva, repetia, em uma nova versão, o gesto fundador do indianismo literário e artístico, o qual a ciência vinha procurando desmistificar e substituir. De fato, se o indianismo pode ser em certo sentido considerado enquanto variação de uma temática do sacrifício, alimentando assim um terreno imaginário no qual tanto as contradiçóes entre catecismo e colonialismo ou mesmo capitalismo e escravidão poderiam ser explicadas e encenadas, a antropologia, na medida em que era representada na exposição, oferecia uma nova alternativa de reformulação do vínculo sacrifical em termos de proscrição soberana na qual a ordem política é fundamentada na inclusão da vida nua do nativo em relação à sua exclusão da nação. Essa mudança dramática na estética da diferença, como tentarei mostrar aqui, é mais ou menos contemporânea com as transições legais e políticas do sistema colonial mercantilista para o modo de produção capitalista, no qual "a vida se torna cada vez mais localizada no centro da política do Estado (a qual se expressa agora, utilizando a terminologia foulcaultiana, enquanto bio-política)" (Agamben, 1998: 111).

Da mesma forma em que o discurso indianista não pode estar reduzido a um parâmetro ideológico singular e univocal, porém, a re-inscrição científica da vida e da cultura nativa parecia expressar mensagens contraditórias, mensagens estas que, disseminadas no nível da esfera pública pela Exposição Antropológica, vieram a tornar-se ainda mais diversificadas e complexas. De fato, como indicarei a seguir, o objeto indígena parecia deslocar-se incomodamente entre os estatutos de antiguidade e de espécime, oscilando entre as classificações expositivas da história natural e da história nacional. Como assinala John Manuel Monteiro, o espetáculo da 
ciência que dizia substituir os mitos literários ou artísticos sobre o índio, não obstante, retomava as dicotomias tradicionais entre bons e maus selvagens, tupis e tapuias, passado e presente: "Tema de presença constante no pensamento brasileiro do século XIX, o contraste entre o índio histórico, matriz da nacionalidade, tupi por excelência, extinto de preferência, e o índio contemporâneo, integrante das 'hordas selvagens' que erravam pelos sertões incultos, ganhava, pouco a pouco, ares de ciência" (Monteiro, 1996: 15). Irei aqui tentar traçar o percurso deste campo científico emergente, primeiramente contrapondo os novos discursos sobre "raça" e civilização pré-colombiana presentes na tradição indianista, para oferecer logo uma observação mais atenta sobre o modo em que essas diferentes instâncias operavam no nível de ordem dos objetos expostos. A partir daí discutirei a proliferação das representaçôes visuais de objetos, homens e mulheres indígenas presentes na exposição em pintura, escultura, fotografia e caricatura.

\section{0 outro sacrifical}

A extinção da ordem colonial no Brasil deteriorou ainda mais a situação desfavorável vivida pelas comunidades indígenas desde a época colonial. Conforme indicado por Manuela Carneiro da Cunha (1998: 133-54), a "questão indígena" deixou de ser, durante o século XIX, a da coerção do trabalho (em forma de pagamento de tributos ou escravização permanente), passando a ser a da expansão e assentamento de latifúndios no interior do país. A crescente exposição das comunidades indígenas à vontade alheia, devida à homogeneização do campo adversário, verificava-se com a expulsão dos Jesuítas do país em 1759 e a chegada da corte portuguesa em 1808. Esta última havia se posicionado em defesa dos interesses dos latifundiários e plantadores locais, ao ponto mesmo de restabelecer conceitos e práticas medievais tal como a proclamação da "guerra justa" que sancionara a violência do genocídio, como foi o caso da guerra de Guarapuava ocorrida durante a regência de D. João VI em 1809. A diversidade de interesses e estratégias da era colonial, que tinha proporcionado margens mínimas de negociação aos povos ameríndios, já havia desaparecido por completo ao se proclamar o Império do Brasil em 1822. Apesar da votação favorável na Assembléia Constituinte de 1823 sugerindo a recopilação das práticas políticas provinciais com o objetivo de promover um "Plano Geral de 
Civilização", nenhuma medida foi adotada em favor das comunidades indígenas, permanecendo a lei missionária colonial como único marco legal em que se reconhecia a existência da população nativa. Enquanto o discurso da "conquista pacífica" continuava a predominar ao nível do governo nacional (seguindo a conduta do "patriarca da independência", José Bonifácio), a ausência de uma política nacional claramente definida permitia às províncias continuar com seus próprios avanços militares (como foi o caso do Ceará e Goiás durante a década de 1830, um período marcado por uma autoridade central fraca) com a subsequente construção de postos fortificados, os chamados presídios, que se encarregavam do policiamento das áreas conquistadas, forçando a população indígena ao sedentarismo. A instauração duma cultura de subsistência não foi uma finalidade em si, mas apenas uma maneira de agilizar o processo de transformação das terras comunitárias reconhecidas pela lei colonial em propriedades permutáveis. Esta transformação, promovida pela chamada política de aldeamento, tinha como objetivo a concentração das populações indígenas em "povoados" em cujas vizinhanças foram assentados colonos brancos e mestiços até alcançar um nível de total interpenetração nestas mesmas comunidades que passavam então a ter seus direitos comunais usurpados: tornar-se "civilizado" significava, antes de mais nada, perder seus direitos estatuários (existentes em todo caso quase exclusivamente no nível retórico). Como era de se esperar, a resistência passiva à sedentarização e a deserção das aldeias eram atitudes freqüentes ao largo do século XIX, fornecendo ainda maiores evidências, se alguma outra prova ainda fosse necessária ao discurso dos "modernizadores" e "progressistas" que pregavam a indolência e inaptidão do índio como maior empecilho contra seu desenvolvimento civilizatório.

$\mathrm{Na}$ seqüência das figuras jurídicas que acompanharam o avanço da "civilização" sobre seu exterior "selvagem" (concebido enquanto território e enquanto corpo, o que permitia a troca constante e associações mútuas entre "meio" e "raça"), emergia uma razão biopolítica que urdia a produção da vida nua nos confins do Estado em função da consolidação e expansão deste último. Considerando que, conforme o sugerido por Agamben, o abandono é a relação originária da lei à vida, poderíamos afirmar que a vida indígena ingressou na lei do Estado (diferentemente das leis missionárias que se mostravam mais preocupadas na salvação das "almas" nativas), numa 
forma de exclusão originária que a relaciona ao Estado em termos exclusivamente negativos, ou seja, como uma vida que, em seu processo de "desaparecimento", pudesse estar excluída de seus antigos "direitos de exceção", sem que estes direitos fossem substituídos por conteúdo positivo algum (como, por exemplo, o direito à cidadania). Nesta modulação legal do tropo biológico de "extinção", a vida indígena se torna, então, vida nua, "uma vida que pode ser exterminada mas não sacrificada" (Agamben, 1998: 71), vida situada literal e imediatamente na "misericórdia do Estado", o qual mantém um poder contínuo de decisão sobre sua prolongação ou terminação.

É na luz dessa produção biopolítica de uma vida nua como atividade originária do Estado que devemos posicionar a análise das relações de continuidade e ruptura presentes na Exposição Antropológica com respeito à tradição indianista existente na literatura e belas-artes brasileiras. Seria ainda possível, em um nível mais específico, considerar o cânone indianista como um índex do Estado imperial na negação das suas próprias realidades sociais, proporcionando à classes letradas uma evasão imaginária nas florestas remotas e passados míticos, nos quais, tal como o que ocorre nos grandes épicos clássicos, as origens de uma nova nação poderiam ser pensadas a partir da orfandade e do exílio. Assim mesmo, enquanto a maioria da literatura indianista estava constituída pela "ficção do Estado", as tragédias de índios e mestiços podiam, nas penas de escritores tais como Gonçalves Dias ou Teixeira e Souza - ambos descendentes de mestiços -, servir também como representação da denúncia de exclusão e violência sociais cometidas na época. ${ }^{2}$ Conforme o indicado por David Brookshaw, o indianismo pode ser avaliado na sua vertente mais crítica enquanto denúncia da modernização promovida pelo capitalismo a partir da perspectiva de um éden rural: "É uma literatura da traição: a traição do paraíso nativo americano, e a traição do paraíso que supostamente iria substituir o primeiro o da utopia agrária - por outros paraísos imaginários, todos eles construídos sobre a exploração mais eficiente da natureza e do homem" (Brookshaw, 1988: 8).

O aspecto central da nossa análise, contudo, é o tropo empregado por ambas as tendências da ficção indianista, a "oficial" e a "oposicionista", como maneira de operar as descontinuidades inerentes a toda narrativa mítica de 
origem (“como o então se tornou o agora?”): a imagem do sacrifício. Porque é enquanto uma vítima sacrifical que o Outro indígena pode ser projetado especificando uma nacionalidade brasileira, num estado ambíguo de negação da sua condição real de vida nua, inclusivamente excluído das leis do Estado. Em uma das suas versões mais famosas, no romance Iracema, escrito por José de Alencar em 1865, o sacrifício figura como o preço a ser pago pelo pecado original da miscigenação, a qual, apesar de haver aberto um novo espaço para a nação, destrói os laços ancestrais e leva os amantes ao exílio. O continente americano feminino, na sua sexualidade lasciva e potencialmente (auto)destrutiva, há de ser simbolicamente exorcizado através da oferta sacrifical da própria sedutora, cujo corpo erótico representa o espaço liminar do Estado: um lugar necessário de iniciação que precisa ser imediatamente exorcizado e re-inscrito pela lei do viúvopai que impõe sobre o corpo morto da sedutora uma moral familiar. ${ }^{3}$ Conforme veremos a seguir, a emergência da antropologia, enquanto saber imparcial, contrariamente ao desejo e à empatia com um nativo imaginário, desafiou o mito sacrifical de fundação do indianismo, ainda que a "ciência” tivesse que esperar pelo advento da República para tornar-se o local exclusivo de enunciação da diferença enquanto vida nua. Vista desta perspectiva, a Exposição Antropológica surge exatamente enquanto tentativa paradoxal de re-ritualização da captura biopolítica da vida nua, como local nacional de iniciação.

\section{Figura 1}

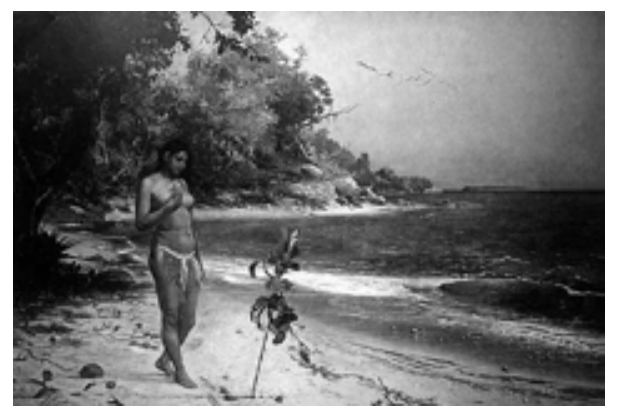

Figura 1: José Maria Medeiros, Iracema, pintura a óleo, 1881. Museu Nacional de Belas Artes, Rio de Janeiro. ${ }^{4}$ 
Embora com base na fantasia e nas modulaçōes do cânone romântico antes do que no conhecimento imediato das culturas nativas, foi o indianismo literário que despertou o interesse arqueológico e lingüístico no Brasil. O poeta romântico Gonçalves Dias doaria ao Museu Nacional algumas de suas primeiras coleçôes etnográficas compostas por objetos adquiridos numa viagem ao interior do Pará em 1859, como membro da primeira expedição científica brasileira. Gonçalves de Magalhães já havia publicado em 1860 o seu Os indígenas do Brazil perante a história, enquanto Domingos Soares Ferreira Penna (diretor do Museu Paraense, fundado em 1871) e João Barbosa Rodrigues (organizador do efêmero Museu Amazônico, e diretor do Jardim Botânico do Rio) realizariam escavaçōes arqueológicas e recopilariam lendas e canções das comunidades Tapuia do Amazonas (Azevedo, 1994: 409-61; Romero, 1888: 127-8). Uma das primeiras tentativas em apresentar uma síntese destes novos saberes foi a obra O selvagem, de José Vieira Couto de Magalhães, escrita entre 1874 e 1875. Este trabalho havia sido solicitado pelo comitê organizador da exposição nacional de 1875 , presidida pelo próprio imperador D. Pedro II, e subseqüentemente posto à mostra no pavilhão brasileiro da feira mundial realizada na Filadélfia. A maior parte do texto - exposição antropológica portátil que atravessava os registros da paleontologia, arqueologia, lingüística, antropologia física e social, filologia e geografia - apresentava um curso prático em tupi-guarani, respaldando a crença do autor na interação lingüística enquanto meio da "conquista pacífica". A obra trazia ainda um texto de Magalhães (que já havia fugazmente incursionado na ficção romântica) no qual o autor elaborava entusiasticamente uma fusão da ideologia política de utopia rural levada a cabo pelo indianismo literário com alguns dos mais "avançados" paradigmas científicos, no intuito de moldá-la a um projeto político de uma modernidade miscigenada. Magalhães lançava no início do seu texto a pergunta: "Que proveito temos nós tirado dos selvagens?", para depois oferecer sua resposta:

Tiramos nada menos do que a metade da população actual do Brazil, não da população que ocupa os altos cargos, as funçōes publicas, os salōes, os theatros, as cidades; mas da população que extrahe da terra milhares de productos que exportamos ou consumimos; da população quasi unica que 
exerce a industria pastoril; da população sobre quem mais tem pezado ate hoje o imposto de sangue, pois é o descendente do índio, o mestiço do índio, do branco e do preto o que quasi exclusivamente ministra a praça do pret, ou o marinheiro. S. A. Real, presidente comissão, commandando o nosso exercito na guerra do Paraguay, vio nos homens de côr, de que se compunha a quasi totalidade das praças de pret, um transumpto da população operaria do Brazil (Magalhães, 1876: xxii).

O que Magalhães roga ao monarca - e também presidente da Exposição Nacional - a enxergar é exatamente a vida nua que existe sob o mito sacrifical do Estado imperial, a diferença originária entre "o povo" enquanto "população ocupante de altos cargos" e a multiplicidade fragmentária de corpos marcados não por seus cargos, mas sim pela sua raça (uma vida identificada não pela sua função política, mas sim pela sua mera natividade, uma vida imediatamente biológica). Magalhães argumentava que a inclusão exclusiva havia se tornado problemática, já que ela entrava em conflito com o recrutamento da "população atual" para exercer uma função claramente política - a participação em guerra - , daí a necessidade de se politizar a vida nua. Magalhães, em outras palavras, denunciava a falta de uma razão propriamente biopolítica que pudesse oferecer uma nova articulação entre o "povo" político e o biológico, cuja separação, por sua vez, ameaçava a coesão do Estado-nação. Com o intuito de obter essa articulação, Magalhães trazia o evolucionismo darwiniano para a análise da cultura folclórica rural, argumentando que esta última era a expressão cultural de um processo gradual de adaptação do homem ao meio ambiente, no qual prevalecem os traços raciais mais funcionais à sobrevivência e fortalecimento da coletividade nacional.

Apesar da adoção de uma linha de argumento evolucionista, $O$ selvagem foi rapidamente rechaçado pelos escritores positivistas da "Geração de 1870 ", que questionaram a promoção da mestiçagem enquanto modelo biopolítico de integração nacional, insistindo, ao contrário, na necessidade de ruptura com os temas relacionados ao indianismo como condição prévia para o ingresso do Brasil na modernidade. Sylvio Romero, portavoz da "Escola do Recife", lançou sua crítica à cumplicidade de Magalhães junto à "índio-mania" oficial que havia transformado o Brasil na mais atrasada e auto-indulgente nação das Américas, idealizando uma população 
indígena que se situava entre as menos desenvolvidas do mundo. Segundo Romero, em vez de reivindicar uma falsa ficção de origens nativas, os estudos da cultura popular no Brasil deveriam dedicar-se à sua fusão particular de elementos luso-africanos: "Não é só, e isto escapou ao Dr. Couto de Magalhães e a todos os indianistas exagerados, não é só o tupy que vae transformando a língua portugueza; são também muitos idiomas africanos falados no Brazil ha tres séculos e meio" (Romero, 1888: 59). Mais digerível para o gosto de Romero resultava um estudo publicado no primeiro volume do novo jornal do Museu Nacional, surgido no mesmo ano de publicação de $O$ selvagem, o qual havia despertado o rápido e crescente interesse em antropologia física no Brasil durante as últimas décadas do século XIX. Seus autores, Rodrigues Peixoto e Lacerda, estavam instalados no novo laboratório fisiológico do museu (o primeiro centro experimental para ciências naturais na América Latina), mantendo-se em contato com os mais famosos osteologistas europeus, tais como Broca, Serres ou Quatrefages, a quem haviam fornecido crânios retirados de cemitérios indígenas para o estudo comparativo de anatomia humana. ${ }^{5} \mathrm{~A}$ craniologia - ciência iniciada finais do século anterior por Blumenbach e dedicada à mensuração de crânios humanos com o objetivo de elucidar as propriedades morais e intelectuais de indivíduos e raças - constitui também o quadro disciplinário do trabalho de Rodrigues Peixoto e Lacerda, um texto saturado de imagens cranianas seguidas por longas tabelas de mensuração antropométrica. Após o exame de espécimes "pré-históricos" e de crânios coletados de índios mortos numa campanha militar punitiva em Minas Gerais, os dois fisiologistas chegaram à previsível conclusão de que os indígenas brasileiros, ao lado dos esquimós e dos habitantes da Patagônia, ocupavam a posição mais baixa na escala de evolução humana das Américas, num estado biológico de selvageria que havia se mantido imutável por mais de 3000 anos. Na sua diferença abismal em comparação ao homem civilizado, apoiavam a hipótese poligenista de várias origens humanas diferentes:

Pela sua pequena capacidade craneana os Botocudos devem ser collocados a par dos Neo-Caledonios e dos Australianos, isto é, entre as raças mais notaveis pelo seu grão de inferioridade intellectual. As suas aptidões são, com effeito, muito limitadas e difficil é fazê-los entrar no caminho da civilisação (Lacerda \& Peixoto, 1876: 71-2). 
O artigo de Rodrigues Peixoto e Lacerda sugeria, além do mais, uma ruptura radical com o arquivo indianista, que o colecionismo arqueológico e etnográfico de autores como Couto de Magalhães ainda tomava como seu quadro de referência, ainda que transformado através do rigor disciplinário. Ao lado oposto se situavam os fisiologistas de formação médica, como no caso de Lacerda, que defendiam a adesão incondicional aos novos discursos científicos de cunho biológico e militantemente racistas pregados pelas novas "Sociedades Antropológicas" que desafiavam o humanismo e o "preconceito" monogenista dos seus adversários, os etnólogos. ${ }^{6}$

O conteúdo utilitarista desta nova antropologia física, posta em evidência na sua patologização de aspectos culturais não subsumáveis ao regime de produção do capitalismo imperial, respondia, antes de mais nada, à crescente demanda por matéria-prima que gerou, conseqüentemente, na expansão territorial da zona de produção e na manutenção da mão-de-obra de baixo custo (uma questão de extrema urgência no Brasil, onde o trabalho escravo vinha sofrendo um drástico declínio, mesmo antes de 1888). A avaliação científica das capacidades exibidas por determinados grupos em "entrar no percurso da civilização", neste contexto, tornou-se um fator importante, que demandava a escolha de uma opção entre coagir a população nativa à atividade laborial ou incentivar o repovoamento de uma área com força de trabalho imigrante, opção defendida pelo zoólogo e diretor do Museu Paulista, Hermann von Ihering, no controversível artigo incluído na apresentação do Estado de São Paulo na Louisiana Purchase Exhibition em 1905. ${ }^{7}$ Estas tendências conflitivas dentro do discurso científico, apresentadas na Exposição Antropológica de 1882, pareciam competir entre si na sucessão do indianismo romântico enquanto elemento gerador de identidade e diferença. Elas se faziam presentes tanto no nível expositório quanto nos rótulos, comentários e outros textos que emolduravam os objetos do evento. Suas diferenças formais e ideológicas estavam, não obstante, centradas numa preocupação com reformular o mito sacrifical que tinha ocupado o cerne das atençôes do indianismo literário e artístico em termos duma vida nua simultaneamente sujeitada e excluída do domínio do Estado. Ironicamente, no seu aspecto de ritual público, em que a "ciência" reclamava ter sucedido a literatura enquanto discurso da verdade sobre a 
nação, a exposição se referia à vida indígena, mais do que nunca, em termos de sacrifício, oferecendo ao olhar os restos duma vida ao desnudo.

\section{Ritos de passagem}

Uma floresta de lanças, abrindo-se em forma de leque ao redor de escudos e arcos, penduradas em paredes e tetos formando motivos geométricos abstratos, energias atávicas desprendendo-se de algum centro místico vazio. Blocos de escuridão montados contra a claridade de paredes brancas; tetos altos, de arquitetura neoclássica, destacando-se sobre o excesso caótico da selvageria, onde objetos e corpos se desdobram, assumindo aparências estranhas como imagens refletidas nos pedaços de um espelho quebrado. As fotografias da Exposição Antropológica tiradas por Marc Ferrez realçavam o efeito atordoante dos objetos expostos através do arranjo meticuloso dos planos: em primeiro plano, sobre uma forragem de ervas e terra seca, uma mulher indígena trajando chapéu e saia aparece carregando uma cesta, rodeada por duas aves aquáticas (empalhadas), enquanto mais ao fundo alguns homens saem em canoas para a pescaria (sua semelhança física é sinistra). Ainda mais ao fundo, dois personagens nus portando pérolas ou penas posam ao lado de uma cabana. Não podemos estar totalmente seguros sobre estes últimos (diferentes dos canoeiros tanto em estatura quanto em vestimenta), mas a existência de fotos registradas a partir de diferentes ângulos do mesmo salão confirma plenamente que as personagens situadas em primeiro plano são, de fato, estátuas de gesso elaboradas a partir dos moldes extraídos pelo escultor Leon Deprès dos índios Xerentes, vestidos em trajes típicos das comunidades nativas. 


\section{Figura 2}

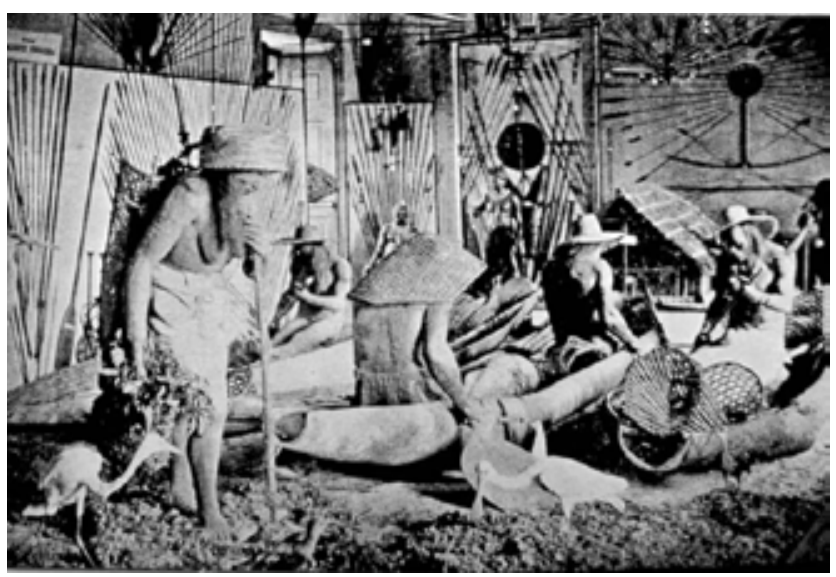

Figura 2: Marc Ferrez, "Exposição Antropológica”, em: João Baptista de Lacerda, Fastos do Museu Nacional do Rio de Janeiro. Recordações históricas e cientificas fundadas em documentos authénticos e informaçóes verídicas. Rio de Janeiro: Imprensa Nacional, 1906.

Lacerda, num guia do Museu Nacional publicado em 1906, descreve a exposição da seguinte maneira:

Armaram-se nas salas da exposição cabanas com as redes e apetrechos domesticos do índio, canôas e ubás, como no acto da pesca; figuras de índio na caça, tudo por imitação do natural. As bellas colleçõos de ornatos e vestimentas de pennas, que o Museu já possui, ficaram num arranjo mais artistico; as armas, as frechas, os maracás, os borés, os tacapes, as zarabatanas, os arcos ocupavam grande extensão da sala; os machados de pedra, os polidores, os instrumentos de syenito, os almofaruzes, os tembetás, etc., formavam pela sua regular disposição quadros dignos de ver-se e compararse. o curara nas suas cabacinhas panellinhas de argila, as settas, as aljavas, os curabis de caça hervados na ponta com aquele veneno, constituiam um grupo de objectos que interessavam sobretudo ao physiologista. Amostras de carvão, de ossos de aves e de espinhas de peixe estrahidas dos sambaquis, uma planta topographica dessas exquisitas formações conchyologicas; craneos humanos e esqueletos dalli procedentes, utensis de pedra e pontas de frecha formavam outro grupo que attrahia a atenção dos visitantes. [...] Cada especie de amostra correspondia a uma tribu, tornando-se dest"arte facil fazer-se a comparação entre os artefactos da mesma especie, pertencentes a tribus differentes. (Lacerda, 1906: 58). 
Dos salōes utilizados para o evento, três estavam dedicados à "Etnografia", expondo "grupos vivos" que ilustravam a vida cotidiana nas aldeias nativas, e várias vitrines com utensílios e armas. A "Arqueologia" ocupava dois outros salóes exibindo, acima de tudo, as coleçóes de cerâmica e utensílios de argila provenientes do Amazonas, coletadas por Netto numa recente expedição realizada pela província do Pará. Ainda nestes salóes se podia admirar coleções similares de outros naturalistas do museu, tais quais Domingos Ferreira Penna e Orville Derby, assim como peças descobertas nos sambaquis do Sul do país por Charles Frederick Hartt. Um outro salão designado à "Etnografia e Arqueologia" continha peças de olaria e um grande número de enfeites, particularmente uma magnífica coleção de mantos e cocares de penas de numerosas tribos, desde as mais "antigas" às mais "modernas". A seção de "Antropologia", ocupando apenas um dos salóes da exposição, mantinha expostos esqueletos e crânios exumados de cemitérios nativos, desenterrados pelo próprio Netto nas áreas habitadas pelos índios Temembé na parte alta do rio Capim. Outras amostras de esqueletos e crânios pertencentes ao laboratório do museu, as mesmas usadas por Rodrigues Peixoto e Lacerda no seu artigo de 1876, estavam também, quase certamente, expostas neste salão. O saláo final da exposição - a "Sala Anchieta" - havia sido reservado para as representaçôes educacionais e artísticas sobre o índio: estudos realizados sobre a língua tupi assim como outros trabalhos de etnografia e antropologia americanas doados pela $\mathrm{Bi}$ blioteca Nacional, pinturas a óleo de diferentes tipos indígenas (especialmente comissionadas a artistas como Aurélio de Figueiredo e Melo e Décio Villares), assim como fotografias, imagens impressas e aquarelas do acervo pessoal do imperador. Todos estes objetos documentavam a tradição indianista nacional que a exposição, ao mesmo tempo, reconhecia enquanto seu ponto de origem e de esquecimento: aquilo que se tentava deixar para atrás (Netto, 1882; Barbosa Rodrigues, 1882).

É importante observar aqui que o evento - assim como atestavam seus próprios organizadores - poderia ser interpretado enquanto uma reorganização monumental do status e valor dos objetos expostos na "Sala Anchieta", sob a luz do discurso "científico" mantido pela "evidência material" dos objetos. O novo "enfoque", assim ficava insinuado, poderia tanto reduzir quanto aumentar a distância em relação ao "Outro" que se mostra- 
va de uma maneira muito mais atávica e estranha quando submetido aos sofisticados aparelhos de captura utilizados pela ciência. De todas as maneiras, ainda se mantinha a controvérsia sobre o que exatamente essa nova narrativa científica adiantava. De início, o próprio nome do evento levantava uma série de questôes: por que uma "Exposição Antropológica" se os materiais arqueológicos e etnográficos, e até mesmo os literários e artísticos, prevaleciam na exposição sobre aqueles propriamente identificados por seu caráter "antropológico" (um termo reservado, na época, ao estudo fisiológico de "raças" não européias) e quando ainda o próprio diretor do museu, Ladislau Netto, segundo suas publicações entre 1870 e 1880, na tentativa de pressionar o governo imperial a financiar a construção de um novo museu dedicado exclusivamente à população ameríndia do Brasil, havia empregado reiteradamente outras nomenclaturas, tais como "arqueologia" ou "etnografia"? ${ }^{8}$ Ao passo que os fisiologistas, como no caso de Lacerda, liam a opção pelo termo "antropologia" como um convite para expor as implicações políticas das suas posturas científicas (a questão, expunha Lacerda na sua contribuição ao jornal da exposição, poderia se reduzir à comparação da utilidade entre índios e negros para o trabalho físico prolongado, onde os últimos superavam amplamente os primeiros), outros contribuidores como J. Serra se opunham acirradamente ao "utilitarismo ianque" e reivindicavam a tradição latina dos "Ramiros, Palma, Vicuña [Mackenna] e outros escritores da América do Sul, que apreciam o serviço do índio, que deles tiram proveito, aconselhando a catequese e civilização por meios brandos e suasórios" (Serra em Mello Moraes Filho, 1882: 51).

Se o enfoque a adotar sobre o Outro nativo continuava sendo objeto de controvérsia, o ponto de vista que regulava a produção de objetos e espectadores na exposição não podia senão resultar numa montagem visual ambígua e multifocal de formas visuais que com freqüência pareciam se excluir mutuamente. Das evidências deixadas sobre a exposição, podemos discernir pelo menos quatro formas diferentes de visualisação: primeiramente os "grupos vivos" constituídos por figuras de gesso as quais, tal como pertencentes a um diorama aberto, dramatizavam os objetos etnográficos encenando um "instante congelado" da vida nos povoados nativos que o observador podia espiar sem ser visto - encenação da ficção etnográfica do "campo" enquanto espaço autônomo e não afetado pela presença do observador. Estas exposiçôes in-situ, embora bastante comuns 
nos gabinetes de cera e outras atrações populares nas cidades européias, haviam apenas se tornado uma expressão regular nas exposições dos $\mathrm{Ou}$ tros coloniais, seguindo o uso extensivo de cenas da vida cotidiana expostas nas feiras mundiais, assim como nas grandes lojas de departamentos na segunda metade do século XIX, com o objetivo de simular o exótico e de estimular o desejo consumista pelas últimas tendências da moda. $\mathrm{O}$ folclorista sueco Arthur Hazelius havia adaptado estas figuras de cera para o seu Museu de Etnografia Escandinava, inaugurado em 1873, cujas inovações da composição de "grupos vivos" tinham grande impacto na museografia alemã e, através de Franz Boas, também na norte-americana, de etnografia e tradições populares. ${ }^{9}$ Ao contrário de Hazelius e Boas que defendiam as representações de "grupos vivos" enquanto alternativa culturalista e contextualizadora à tradição tipológica de classificar objetos de origens dispersas segundo as suas semelhanças formais, Netto e os outros cientistas do museu envolvidos no desenho da Exposição Antropológica não puseram objeção em justapor os "grupos vivos" e a exibição tipológica de objetos, como nas vitrines de pontas de flexas e machados de mão (Fig. 3) ou mesmo de cachimbos e instrumentos musicais (Fig. 4), também fotografados por Marc Ferrez. O arranjo tipológico também parece ter prevalecido, a julgar pelas ilustrações do sexto volume dos Archivos do Museu Nacional - a edição especial do jornal do museu sobre a exposição - na seção de materiais arqueológicos (Fig. 5).

\section{Figura 3}

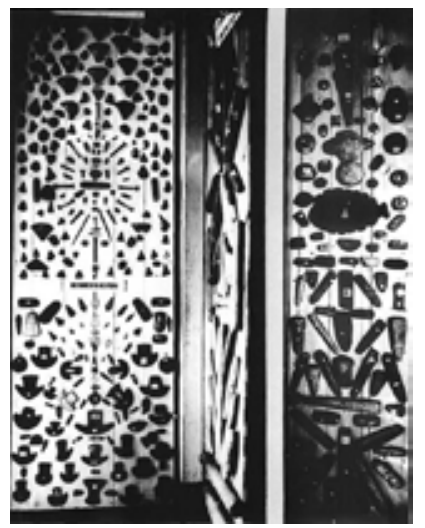

Figura 3: Marc Ferrez, "Exposição Antropológica Brasileira: Artefatos e aspectos da vida indígena (peças expostas)", albumina, ca. 1882. Biblioteca Nacional, Rio de Janeiro. 
$144 \cdot$ Jens ANDERMANN

\section{Figura 4}

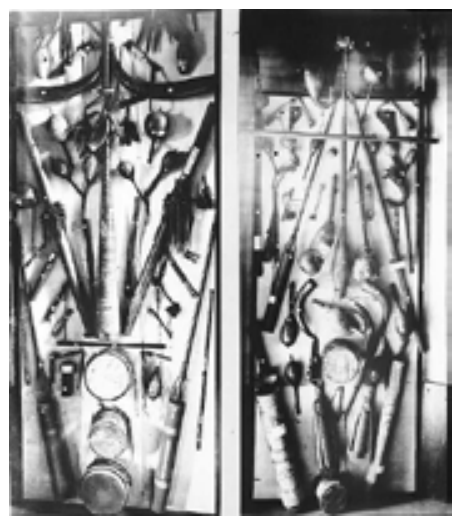

Figura 4: Marc Ferrez, "Exposição Antropológica Brasileira: Artefatos e aspectos da vida indígena (instrumentos musicais)", albumina ca. 1882. Biblioteca Nacional, Rio de Janeiro.

\section{Figura 5}

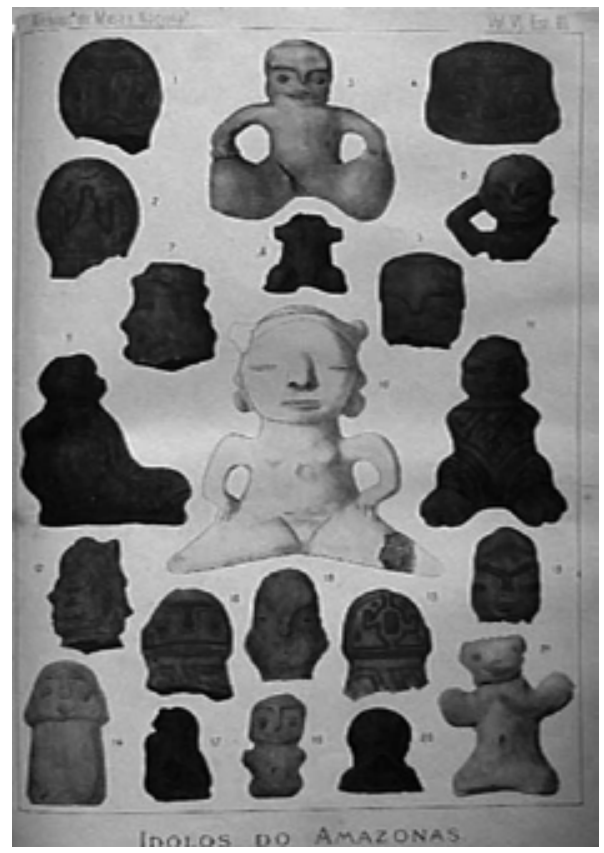

Figura 5: Ilustração em Ladislau Netto, "Investigações sobre a archeologia brazileira", Archivos do Museu Nacional VI (1885). Museu Nacional/UFRJ, Rio de Janeiro. 
Os princípios que organizavam estas "famílias de objetos" teriam sido, quase certamente, os mesmos indicados por Netto numa circular enviada em 1890 aos funcionários do museu, na qual ele distingue oito "classes" etnográficas e arqueológicas (Netto, 1890). Além de "utensílios de caça e pesca" e "objetos festivos e musicais", outras classes apareciam compostas por itens funerários, utensílios domésticos, penas e outros enfeites, assim como o que se poderia denominar de "traços lingüísticos" (uma classe contendo vocabulários nativos, lendas, inscriçóes, manuscritos e material publicado sobre temas indígenas) e reconstruções de canoas, cabanas e povoados inteiros. Neste esquema classificatório, quase certamente modelado no acervo exibido na Exposição de 1882, os "grupos vivos" estavam imaginariamente postos dentro de uma outra "grande vitrina" e, assim sendo, pareciam estar inseridos dentro de um paradigma geral de classificação derivado da tradição tipológica e da sua visão comparativa e evolucionista da cultura, exposta no trabalho de Pitt Rivers, Principles of Classification, de 1874. Apesar do esforço de Netto em designar um princípio totalizador e homogêneo de classificação, é difícil imaginar como os "grupos vivos", juntamente com os manuscritos e livros de estudos sobre o índio poderiam se moldar dentro deste padrão rígido e arborescente de evolucionismo tipológico. Na verdade, da mesma maneira que as pinturas e gravuras exibidas junto aos materiais impressos apareciam na exposição, oferecendo ao espectador alternativas visuais à comparação tipológica sugerida pela exibição de utensílios e armas. Ainda num outro plano, devemos tomar em consideração as amostras "antropológicas" de esqueletos e crânios: pelo que me consta, não se preservou nenhum registro visual destes materiais, porém, considerando-se a descrição oferecida por Lacerda e pelo próprio catálogo da exposição, podemos inferir que pelo menos alguns dos restos humanos tenham sido exibidos em reconstruções de cemitérios, ao passo que outros crânios e esqueletos hajam sido expostos em vitrines facilitando a comparação fisiológica entre os diferentes "tipos raciais".

Talvez um dos aspectos mais significativos da Exposição Antropológica tenha sido a rapidez no planejamento, organização e abertura do evento. Segundo o próprio Netto, a idéia de organizar uma mostra antropológica e etnográfica nasceu já em 1880, ao ter ele a certeza de que seu outro projeto de criação de um museu completamente novo não iria ser realizado 
(Netto, 1885a: 9; 1885b: ii). Mesmo assim, ainda em janeiro de 1882, ou seja, seis meses antes da abertura da exposição, vemos o diretor do Museu Nacional viajando ao norte à procura de materiais para expor no evento. Na Ilha de Marajó, província do Pará, Netto passou algumas semanas escavando utensílios de barro e argila dos túmulos funerários. Ao "terminar" então sua pesquisa arqueológica, reservou as duas últimas semanas antes de tomar seu vapor de volta ao Rio, onde desembarcou no dia 5 de março, para uma expedição etnográfica e antropológica na parte alta do rio Capim. Desde Belém, onde deixou suas descobertas arqueológicas antes de continuar suas pesquisas, Netto relatava: "Agora, deixando a Arqueologia em repouso, vou ocupar-me da Antropologia e da Etnografia e sigo por estes dois dias para o interior a fim de me pôr em contacto com umas três tribos selvagens, cujos costumes quero estudar ao vivo, e de perto, e cujos cemitérios vou revolver para deles exumar os ossos destes filhos primitivos das nossas selvas" (Netto em Duarte, 1950: 164-5).

Três tribos visitadas em duas semanas. E muito selvagens. Vida real, cemitérios. Para Netto, "o interior" parecia representar um grande reservatório de "material" - vivo e morto - que precisava ser "revolto" para se descobrir as peças mais fascinantes; pedras e ossos que irão, eventualmente, ocupar as prateleiras a elas reservadas no museu. Estavam destinadas a fazer parte da exposição antes mesmo de haverem sido "descobertas". Netto havia levado menos de quatro meses para classificar e preparar suas descobertas para expor na exibição, em que formaram parte substancial do material exposto, sendo posteriormente integrados às coleções etnográfica, arqueológica e antropológica do museu. $\mathrm{O}$ encontro etnográfico com os índios "dont le charactère fut plus exente de ce mélange, qui le rapporte ordinairement moins de civilisation que de corruption" (Netto, 1889: 54), como Netto afirmava numa antecipação precoce a Lévi-Strauss, ocupa menos de duas páginas do seu relato de viagem e parece não haver contribuído com nenhuma influência nas suas idéias científicas, talvez porque um encontro propriamente dito nunca houvesse de fato ocorrido. É que no fundo, para Netto, o colecionador, o Outro existe somente enquanto guardiāo dos materiais que agora precisam ser extorquidos para serem postos no lugar a eles destinados, o museu: "De todos as pilhagens adquiridas passivelmente nestas regiōes, as que mais me agradaram acima de tudo foram 
os esqueletos e os crânios que eu trouxe comigo usando as manhas que eu não chamaria propriamente de infundadas, mas que me parecem altamente necessárias para a ciência” (ibid.: 58). Troféus, deveras: para Netto a etnografia é apenas um novo ramo do colecionismo. Seu objetivo não é a compreensão das diferenças culturais, mas sim a sua ilustração, considerando-se que a diferença está sempre prestes a ser emoldurada (pela arqueologia e antropologia, as duas práticas disciplinárias que enquadram o "trabalho de campo" de Netto) enquanto não-simultaneidade, ou alocronia (Fabian, 1983). Já que o "Outro selvagem” é um ente imperfeito, um precursor, ele precisa ser recolhido tanto como excedente quanto como remanescente daquela região primitiva do espírito que ele até poderia ajudar a elucidar e controlar:

Toutes les questions d'anthropologie se résument, comme vous le savez, en deux problèmes essentiels. Le premier a pour but la détermination de la genèse humaine; le second, qui se lie intimement au premier, consiste dans la discussion des hypothèses du monogénisme ou de polygénisme, par rapport aux lois de l'évolution dans l'echelle zoologique. [...] Le doute de la pensée troublée par le fameux to be or not to be, l'angoisse d'un cerveau en lutte avec lui-mêm, dans les abimes de l'inconnu, voilà ce qui exprime le mieux l'état de l'esprit et du cœur de ceux qui s'appliquent à l'étude des anciens peuples de notre continent. ${ }^{10}$

A mudança de enfoque da antropologia à autobiografia, da origem do homem americano à questão shakespeariana com que o cientista se depara na sua busca pela verdade, não surpreende quando contextualizada no efeito de alocronia que esta narrativa fabrica reiteradamente. Se o Outro representa o alvorecer da humanidade, o retrocesso mental do antropologista pode realmente ser considerado enquanto um rito de iniciação, uma viagem ao espaço liminar onde humanidade e animalidade se confundem. Talvez, então, pudéssemos ver no famoso conceito de Van Gennep (1909), antes de mais nada, uma autoreflexão distanciada e exótica desta disciplina emergente que é a antropologia e da maneira que ela permite à subjetividade se autoconstituir contra o elemento primitivo, cujo espaço ela não obstante precisa atravessar. Meu objetivo é o de trabalhar dentro do conceito de iniciação para a compreensão de um momento de passagem na constituição cultural e política da sociedade brasileira a qual, como 
venho demonstrando aqui, expressa-se num nível de reformulação da tradição indianista. A minha preocupação, desta forma, é a de considerar a antropologia enquanto prática cultural, da mesma maneira que Michael Taussig sugere justapor de novo "os termos da pesquisa colonial, reciclando e, desta forma, transformando a antropologia desenvolvida na Europa e América do Norte através do estudo dos povos colonizados, aplicando-a em relação às sociedades nas quais esta antropologia foi instituída, de forma que os termos e práticas impostas sobre e apropriadas desde as colônias ressurjam com uma nova intensidade" (Taussig, 1993: 224).

Nos escritos de Netto, o espaço iniciático das culturas indígenas brasileiras é ainda posto em comparação com outro espaço de viagem e iniciação: o das universidades européias, onde ele entrou pela primeira vez em contato com um interesse arqueológico na "pré-história” brasileira:

Il est vrai que dès 1867 , poussé par les travaux de Louis Lartet qui, à cette époque, $\mathrm{m}$ 'engageait à entreprendre des études comparées entre la céramique des proto-celtibères et la poterie primitive du Brésil, je me suis trouvé engagé et presque involontairement entrainé dans des essais de ce genre. Je le faisais plutôt comme simple collectionneur de matériaux épars qu'à tritre de chercheur expérimenté et sûr; je le faisais, enfin, au nom et au profit du Muséum National, en m'aidant de la presse, grâce à laquelle cet établisssement pourra revendiquer tôt ou tard la priorité des investigations de ce genre au Brésil. ${ }^{11}$

Uma vez consagrado enquanto diretor do museu e, após as campanhas promovidas pela imprensa que resultaram na obtenção de quantidades abundantes de objetos indígenas, Netto iria tornando-se gradualmente um experiente antropologista, desafiando até mesmo as "visões restritas" dos seus antigos mestres europeus e americanos:

Charles Hartt commençait à avoir dès lors dans mon esprit une justification suffisante des réserves préméditées qu'il avait montrées à l'égard des questions ethnologiques de notre continent. Mais, soit pour la suite du caractère même de la nature humaine, soit pour toute autre raison, il ne m'était pas possible de me soumettre entièrement à la manière de voir si restreinte de beaucoup d'ethnologistes nord-américains. Ce qui ne me le permettait pas non plus, c'étaien les innombrables documents placés sous mes yeux, demandant la raison de leurs analogies et de leurs admirables 
ressemblances avec des antiquités d'autres peuples primitifs, sinon du vieux monde, du moins de notre continent. Je ne pouvais pas nier ces ressemblances, car elles sautent aux yeux. ${ }^{12}$

A exposição, em outras palavras, tornou aparente o que a intuição de Netto havia já suspeitado: a saber, o parentesco entre os "primitivos brasileiros" e outros ameríndios, assim como o possível parentesco até mesmo com as velhas civilizaçôes européias e asiáticas. A descoberta simultânea dos "selvagens" e das "belas relíquias" em sua viagem de campo, uma conclusão previsível, visto que o único interesse do colecionador reside em extrair estes últimos da possessão daqueles, levou Netto à dedução de que a conecção entre ambos os elementos deveria ser, quando muito, remota. Havendo então posto entre parênteses a "selvageria" (utilizando um argumento que toma distância simultaneamente do Outro interno e exterior, o índio e os sábios europeus e americanos, definindo assim um novo sujeito híbrido e intersticial, o cientista brasileiro), Netto pôde finalmente afirmar os rastros da sua recém-descoberta época de ouro brasileira como patrimônio do Estado imperial da Segunda Regência: "os homens dos sambaquis eram os descendentes degenerados de nações bastante avançadas, as quais eles conservaram, como os povos antigos do oriente no seu exílio, pelas últimas relíquias, os vasos sagrados e os penates..." (Netto 1885a: 26). As mulheres indígenas, reconhece Netto, enquanto guardiās da memória coletiva nas suas produçôes de motivos têxteis e cerâmicos, mantiveram o refinamento intelectual de seus antepassados, ao contrário de seus maridos que haviam regredido às trevas da ignorância e da superstição.

Embora bastante ridicularizado na época pela sua insistência em estabelecer um parentesco clássico para a sua "época de ouro nativa" - a qual o havia levado alguma vez a classificar como de origem fenícia uma inscrição encontrada no Amazonas -, Netto conseguiu, através de sua hipótese de um virtuoso império indígena desaparecido, ao mesmo tempo negar e reinventar o mito sacrifical do indianismo romântico no tempo amplamente expandido da antropologia científica. A exposição foi de fato uma espetacular e monumental tentativa de simular a experiência iniciática de autoinvenção do sujeito cientista no seu simultâneo reconhecimento e diferenciação do Outro interno, um tropo ao redor do qual Netto havia organizado seus escritos científicos e autobiográficos (ou melhor, uma maneira acha- 
da por ele de aglutinar estas duas formas de escritura num texto único). A iluminação do sujeito racional e civilizado estava constituída precisamente pela sua autoperda anterior no espaço onírico da alteridade:

Cada um dos que nestas salas nos achamos como que se julga arroubado, repentinamente, e máu grado seu, a uma até então mal cogitada existência. A imaginação, guiada pelo que neste recinto se nos depara e nos maravilha, ora vencendo o espaço, rompe por sobre as ínvias florestas do grande estuário do Amazonas, e vai pousar à beira do lar hospitaleiro dos Ipurinãs, nas márgens do extenso Aquiri ou nas tristonhas malocas dos últimos descendentes dos nobres Tupinarás e Temembés, no alto vale do Capim; ora abstraindo do decurso dos séculos, penetra ao fundo dos necrotérios sagrados dos valentes Aruãs, na ilha de Marajó, e acompanha o ceremonial solene e grave com que vai ser ali depositada a urna funerária, e suntuosamente adornada, a que foram confiados os ossos venerandos do chefe mais bravo ou do mais velho guerreiro da tribu (Netto em Duarte, 1950: 168-9).

A exposição, em resumo, ofereceu uma viagem de iniciação, um vôo de fantasia, durante a qual os visitantes eram convidados a tornarem-se nativos, embarcando em "uma viagem em direção ao outro que nos leva à área proibida do nosso próprio eu”, como James Clifford (1985: 217) descreveu alguma vez a estratégia através da qual propunha confrontar a ordem disciplinária do museu, aceitando ativamente seu sustento fetichista. Mesmo assim, como podemos notar na caracterização de Netto da exposição enquanto um cronotopo ritual, a perda e reencontro da identidade própria nas profundezas metonímicas do exótico e do antigo é perfeitamente compatível à disciplina de ordenação do museu, contanto que os sonhadores sejam logo devidamente instruídos na classificação tipológica que rotula os objetos e oferece aos visitantes um escape das cenas por eles invocadas. Assim sendo, a ciência só podia suceder à literatura por meio de uma nova versão do mito fundacional de uma identidade que emerge a partir de sua passagem pela diferença: o Brasil, para Netto, se havia tornado moderno na medida em que poderia sonhar com a sua própria antigüidade.

\section{Imagens de uma exposição}

Com o intuito de despertar a imaginação dos visitantes com uma experiência de substituição da liminaridade iniciática, a Exposição Antro- 
pológica empregou, de uma maneira inovadora, uma gama variada de disciplinas visuais. As imagens formaram uma parte do aparato de emolduração dos objetos indígenas como significantes de uma estrutura invisível supostamente situada num escalão mais alto da verdade. Da mesma forma em que a estratégia de disposição do material oscilava entre diferentes estéticas expositórias e discursos disciplinários, assim também as representações visuais da Exposição Antropológica se estendiam através de numerosas formas e gêneros visuais, desde as estátuas de Deprès às pinturas e fotografias que documentavam e também integravam a exposição. Os caricaturistas populares, como Agostini, que estiveram presentes no evento, também produziram as suas próprias versóes satíricas, as quais podem ser analisadas enquanto um comentário visual da iconografia apresentada na Exposição: uma casa de espelhos refletindo uns nos outros, chamando ainda atenção para as manchas e rachaduras no vítreo.

Podemos iniciar a nossa análise por aquilo que pareceu ser o registro mais discreto e neutro de imagens, as fotografias de Marc Ferrez que retratavam o material exposto. Ferrez foi um fotógrafo comercial (talvez o melhor do Brasil no século XIX), cuja especialidade era a fotografia das vistas pitorescas do Rio de Janeiro e das suas área vizinhas. Discípulo de Georges Leuzinger, o fotógrafo oficial da corte, Ferrez estabeleceu sua própria companhia em 1867, exibindo o seu trabalho regularmente em exposições tanto no Brasil quanto no exterior, sendo várias vezes premiado. Em 1889, havia sido indicado pela comissão brasileira para a Exposição Universal de Paris para apresentar um album de fotos sobre o país. Estas mesmas fotos foram utilizadas como apêndice para a obra do Barão do Rio Branco, Le Brésil, que, por sua vez, havia sido incluída na Grand Encyclopédie de Levasseur. ${ }^{13}$ Como indicado por Maria Inez Turazzi, as fotografias expostas nas exposições brasileiras, tanto no Brasil como no exterior, tinham a dupla função de ilustrar a abundância natural e exuberância da beleza tropical do país, ao mesmo tempo em que destacavam a modernidade e civilização incorporadas na aparelhagem moderna de captura, resultando numa oscilação constante das imagens fotográficas entre os campos das belas artes e da indústria. ${ }^{14}$ As fotos etnográficas formavam uma parte integral neste imaginário auto-exótico: em 1867, as fotografias de índios amazonenses tiradas por August Frisch, um companheiro de Ferrez no estúdio de Leuzinger, 
foram expostas na seção brasileira da feira mundial de Paris; enquanto o "Palácio Amazonense" na Exposição Universal de 1889, organizada por Netto, exibia fotografias de índios Botocudos, Walpes e mestiços tiradas por Alfredo Ducasble, quase certamente cópias das mesmas fotografias expostas na Exposição Antropológica de 1882. O próprio Ferrez havia fotografado homens e mulheres indígenas em várias ocasiões - ao menos uma vez quando contratado a produzir material para uma pesquisa antropométrica - e havia incluído muitos destes retratos no álbum do Brasil exibido no seu estúdio no Rio de Janeiro. ${ }^{15}$

\section{Figura 6}

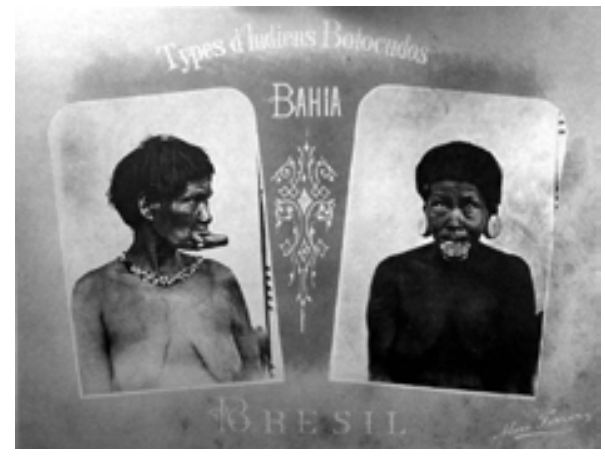

Figura 6: Marc Ferrez, “Types d'Indiens botocudo", albumina, ca. 1874. Iberoamerikanisches Institut, Berlim.

Podemos inferir que a renomada habilidade profissional de Ferrez teria sido recrutada não somente para documentar a seleção dos objetos da exposição, mas também para oferecer uma impressão da sua dimensão iniciática tal como sugerida por Netto, para transformar, enfim, a experiência do vôo imaginário numa imagem portátil. As séries de fotografias estavam divididas em dois grupos: as da exposição, centrando sua atenção na exibição dos "grupos vivos", e as fotografias das vitrines que enfatizavam não os objetos individuais, mas sim a maneira em que se encontravam dispostos. 


\section{Figura 7}

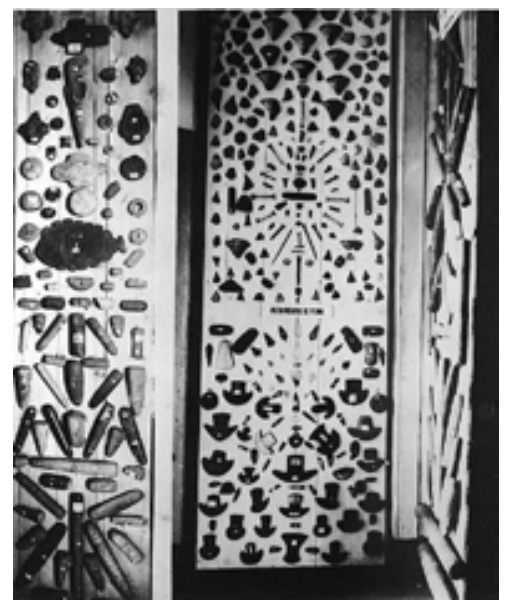

Figura 7: Marc Ferrez, "Exposição Antropológica Brasileira: Artefatos e aspectos da vida indígena (peças expostas)", albumina, ca. 1882. Biblioteca Nacional, Rio de Janeiro.

À primeira vista estas fotos parecem apenas adicionar uma outra guarnição aos objetos já emoldurados pelas próprias vitrines, expandindo ainda mais a cadeia metonímica das retóricas de substituição do museu nas quais a "cultura nativa" se encontra progressivamente significada e sobrecodificada. David Jenkins (1994: 244) descreveu esta expansão metonímica enquanto uma solidificação progressiva de significado, como "a redução de objetos tridimensionais a inscrições no papel, resultado na simplificação do manejo simbólico e conceptual de objetos que estabilizam o significado..." Contudo, deve-se levar em consideração que o "objeto tridimensional" em exibição no museu já havia sido "reduzido e estabilizado", ou seja, arrancado de sua significação cultural e experiencial circunscrita pelo valor de uso. Talvez não seja necessariamente em termos de subtração que a passagem do objeto do museu à fotografia possa ser completamente entendida: por que não poderia a fotografia também ajudar-nos, voluntária ou involuntariamente, a expor as operações prévias realizadas sobre o artefato visando constituí-lo enquanto objeto? Não há nenhuma razão para que as fotografias de objetos - e talvez a fotografia de objetos de museu mais particularmente - deveriam estar destituídas de um punctum, como 
Roland Barthes (1980) havia denominado esse ponto incisivo de claridade onde a imanência da imagem se desmorona.

\section{Figura 8}

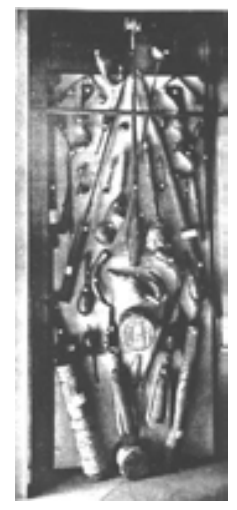

Figura 8: Marc Ferrez, "Exposição Antropológica Brasileira: Artefatos e aspectos da vida indígena (instrumentos musicais)", albumina, ca. 1882. Biblioteca Nacional, Rio de Janeiro.

Vejam-se, por exemplo, as fotos de instrumentos de percussão e zarabatanas tiradas por Ferrez, nas quais a disposição geométrica dos objetos expostos é tanto enfatizada quanto debilitada pelo dramático uso de luz e sombra utilizado pelo fotógrafo, uma assinatura visual que, ao invés de apagar todos os traços de engajamento subjetivo, localiza os objetos no espaço e no tempo do encontro com um espectador, sua apreensão pelo olhar do visitante. Se bem tanto as fotografias como as vitrines são maneiras de apropriação das coisas, de "colocar-se numa certa relação com o mundo que oferece a impressão de conhecimento - e, portanto, uma impressão de poder", no dizer de Susan Sontag (1979), a sua justaposição pode talvez chamar a nossa atenção, curiosamente, ao sentido oposto, à maneira pela qual as coisas nos escapam, até se parecer a despojos, objetos feridos que, amputados da sua utilidade prática apontam apenas para a ausência, em luto pela perda de sentido precisamente ao serem reduzidos à pura significação.

Não estou sugerindo que Ferrez intencionou conscientemente lançar uma crítica da violência implícita em toda exposição material (embora, por que ele não poderia havê-lo feito?). O que quero enfatizar, no entanto, é 
justamente a maneira pela qual a fotografia transforma a exposição de objetos num novo objeto visual que traz à tona alguma coisa já presente na própria exposição, mas naturalizada, tornada invisível pelo aparelho do museu. A fotografia, em constraste, coloca o objeto e o dispositivo de moldura do museu sobre um único e mesmo plano, objetivando a objetificação. No processo do objeto e de seu aparelho de captura em "tornar-se imagem", na sua tomada comum por um outro dispositivo de mimesis espectral, são os dispositivos e agentes de objetificação que se tornam mais afetados do que o material antes já objetificado. A fotografia, neste sentido, cumpre implicitamente uma forma de "vingança do objeto". Desta forma, ela restabelece um sentido de contingência histórica, ao tempo congelado da exibição do museu, justamente por revelar a instantaneidade das suas manifestações.

\section{Figura 9}

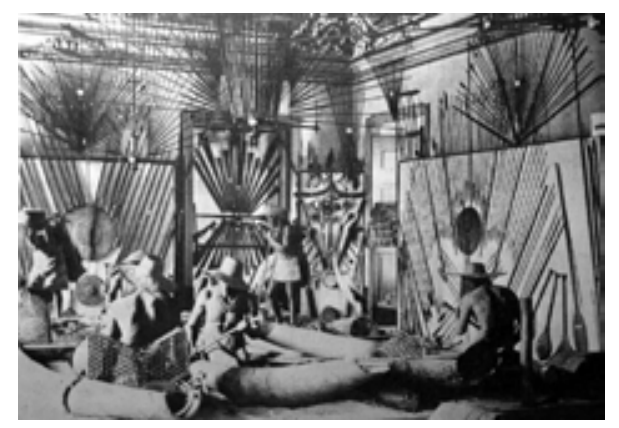

Figura 9: Marc Ferrez, "Exposição antropológica de 1882", albumina, ca. 1882. Iberoamerikanisches Institut, Berlim.

Instantaneidade, quisera sugerir, significa aqui a notação objetiva das tensōes, contradições e lutas históricas que são "esquecidas" na permanência manufaturada pela ordem museológica. Numa outra fotografia da exposição, retratando os moldes de gesso dos pescadores Xerentes, Ferrez reproduz a justaposição do "grupo vivo" com as mostras de troféus através da estruturação planar da moldura fotográfica, escolhendo uma distância focal que reproduz ambos os níveis da exibição, assim como a arquitetura clássica que os envolve, com o mesmo grau de resolução. A imagem é en- 
tão atravessada pela tensão entre a cena autocontida do povoado - "nativos" se movendo pacificamente nas suas atividades diárias - e as lanças, tacos e escudos que os rodeiam formando motivos ornamentais, uma recordação da violência que paira literalmente sobre suas cabeças, ameaçando perturbar, mas, em última instância, sucumbindo à serenidade retilínea do salão neoclássico. Enquanto uma imagem da "vida nativa" no museu, a fotografia oferece ao mesmo tempo uma imagem da ciência, ou ainda da autorepresentação da ciência como substituindo o excedente do Outro, a ferocidade que ele exerce contra a civilização, pela ordem disciplinária da classificação. As disposiçóes de armas - as quais formam um tipo de tela entre os "grupos vivos" e a arquitetura do museu - ocupam precisamente o local onde a força atavística do Outro é tanto invocada quanto contida: uma exterioridade que é constitutiva da interioridade da "ciência", um fetiche da antropologia, a qual, assim como fazem os troféus, indica, mais que qualquer outra coisa, a violência colonial no processo de sua aquisição. ${ }^{16}$

Ironicamente, embora que a fotografia estivesse incubida de documentar e acentuar o ilusionismo dos objetos exibidos, a tarefa de visualização da agenda fisiológica, sugerida mais notavelmente nos mostruários anatômicos de restos humanos, estava encomendada à pintura. Alguns retratos de tipos indígenas (tendo como modelo os índios levados ao Rio), haviam sido encomendados a Aurélio de Figueiredo e Melo, irmão e discípulo do famoso Pedro Américo; e Décio Villares, um jovem pintor e escultor com firmes convicções positivistas e quem iria mais tarde tornar-se o "artista oficial” da República. A julgar pelos trabalhos ainda pertencentes ao acervo do museu, o resultado foi heterogêneo: os retratos pintados por Aurélio de um índio Walpe em tamanho natural, portando penas de cores vivas e mostrando uma longa lança, ainda exposto no vestíbulo do museu, demonstra uma notável confluência com a idealização do indianismo romântico de um guerreiro cavaleiroso; as séries pintadas por Villares de retratos em tamanho pequeno, executados numa atmosfera "científica" mais neutra, excedia a própria tipificação indígena que havia sido demandada ao pintor, convertendo-se num complexo compromisso visual com seus sujeitos. Seguindo ainda uma vertente frenológica, os quadros de Villares enfocavam exclusivamente as cabeças e bustos dos modelos, em perfil ou semiperfil, posicionados à frente de um pano de fundo monocromático (o que adi- 
cionava um aspecto de neutralidade à pintura), removendo qualquer referência a localidades.

\section{Figura 10}

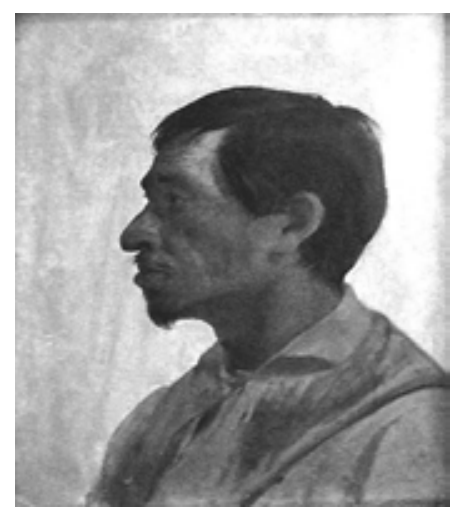

Figura 10: Décio Villares, retrato de caboclo, óleo sobre madeira, ca. 1882. Museu Nacional / UFRJ, Rio de Janeiro.

\section{Figura 11}

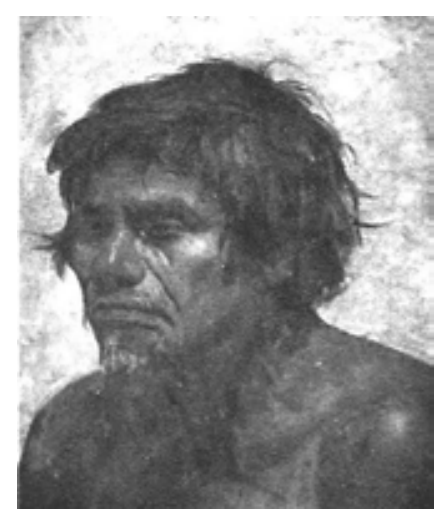

Figura 11: Décio Villares, retrato de índio Xerente, óleo sobre madeira, ca. 1882. Museu Nacional / UFRJ, Rio de Janeiro. 


\section{Figura 12}

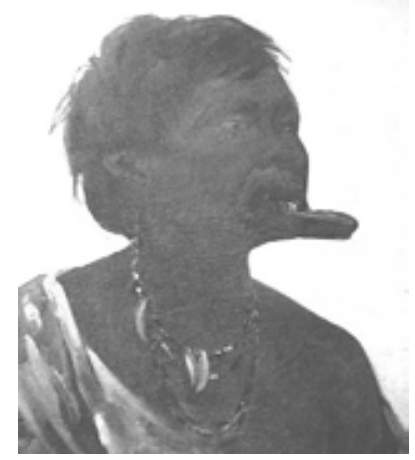

Figura 12: Décio Villares, retrato de índia Botocuda, óleo sobre madeira, ca. 1882. Museu Nacional / UFRJ, Rio de Janeiro.

Da mesma forma, as peças de vestimentas, contrariamente aos quadros de Aurélio, vinham desprovidas de qualquer aspecto de exotismo, mostrando aos espectadores uma fisionomia que se explicava por si mesma e que supostamente denotava os graus de "desenvolvimento moral", distinguindo o semicivilizado caboclo (figura 10) do Xerente de sangue puro (figura 11); ou ainda, ocupando a parte mais inferior da escala evolucionista, uma mulher Botocuda com seu lábio inferior alargado artificialmente (figura 12). A austeridade da moldura visual expunha completamente os modelos a um olhar fisiológico - o espectador não era mais distraído por elementos narrativos ou alegóricos -, um olhar que não era retribuído. É neste aspecto que os retratos dos índios contrastam mais radicalmente com aqueles encomendados a Villares pelos dignatários republicanos antes e após o golpe de 1889, nos quais o olhar dos personagens retratados é severamente retribuído ao espectador reafirmando o poder político e carisma do retratado (Miceli, 1996). Enquanto a biologia determina claramente os termos de compromisso com o Outro, um efeito similar de excesso estético, como o que se apresenta nas fotografias de Ferrez, atravessa também os quadros de Villares, alterando, em última instância, a própria produção de sentidos.

O retrato da índia Botocuda (figura 12), uma imagem particularmente intrigante que evita a tentação de um estranhamento simplista, poderia ser interpretado a partir de uma perspectiva crítica enquanto um local de autoreflexão visual sobre a produção da vida nua. O quadro é, com certeza, mais 
ativamente "encenado" em comparação com as outras pinturas da série, permitindo ao olhar mover-se entre a face da modelo, o seu colar de pedras e garras de onça e o seu pescoço e ombro expostos, acrescentando à imagem uma dimensão sensual inesperada que faz lembrar o investimento erótico perpetuado pelo indianismo sobre a figura do índio. A nudez parcial do corpo feminino adornado com o símbolo da ferocidade, que em outras imagens tal qual no quadro Iracema (figura 1), de José Maria de Medeiros, havia servido para sublinhar o excesso sensual e disponibilidade deste corpo, sofre uma reversão radical oposta à oferta sexual através da qual o indianismo havia fabricado uma empatia e assim superado a diferença: um "corpo dentado", um corpo que rejeita o olhar do espectador. Enquanto as formas sensuais de Iracema haviam sido corroboradas pelos suntuosos volumes e cores da paisagem romântica de Medeiros, como se a espada cingida de flores, que indica a presença fálica do colonizador, tivesse sido realmente um pincel de artista, a imagem de Villares denuncia a completa incompreensibilidade da fisionomia capturada pela linguagem visual do realismo. A incompatibilidade entre uma forma estética acoplada à noção positivista do real e a outra estética incorporada no físico do seu sujeito, torna-se aqui demasiado ampla para permitir o enfoque erótico sugerido pelo indianismo, como o que parece ter compreendido Villares ao citar e negar simultaneamente a opção à fantasia sensualista. A boca da índia botocuda, com os seus dentes inferiores expostos pelo disco bucal, é literalmente transformada num signo e local de proibição, uma ameaça de castração que interdita o consumo do prazer visual oferecido pelo tropo da exposição parcial (a boca grotesca, como veremos na versão caricata de Angelo Agostini, forma também um aspecto central na associação entre o corpo selvagem e o canibalismo). O que se torna exposto na interdição do investimento erótico é a vida nua, uma vida que não pode ser investida, mas apenas captada pela representação em termos da sua própria impossibilidade, marcando a impropriedade de outra, mesmo de qualquer representação. Porém, desta maneira, os quadros de Villares tornam-se autocríticos do mesmo modo que as fotografias de Ferrez: a austeridade pictórica assume o caráter de uma reflexão sobre a falta que se situa no cerne do real. Ao mesmo tempo, este signo de (des)encontro assume o modo de uma asserção negativa de contemporaneidade: a fisionomia, na realidade, trans- 
forma-se de um significante fenotípico de evolução racial para tornar-se a portadora enigmática de uma biografia (enigmática porque a vida à qual ela se refere está ausente da esfera do bios, ou vida qualificada). Enquanto as fotografias de Ferrez oferecem imagens da exposição e não somente a ilustração dos objetos exibidos, tornando visível a invisível moldura da disposição etnográfica da cultura material indígena, os retratos de Villares desafiam a (des)contemporaneidade imposta aos objetos culturais e também ao próprio corpo do Outro, enfatizando a sua irrepresentabilidade e expondo a falta que transforma em ilusão o espetáculo da diferença.

\section{0 beijo canibal}

A (des)contemporaneidade entre a modernidade e o primitivo anunciada pela Exposição Antropológica como atributo constitutivo, de forma mútua, da ciência e do seu objeto, tornou-se o tema preferencial de satiristas, tais como Angelo Agostini, que elaborou uma história em quadrinhos publicada em agosto de 1882 na Revista Illustrada. Em sua versão, Agostini utiliza o potencial cômico do anacronismo de uma maneira não muito longe da justaposição jocosa entre o contemporâneo e o arcaico que viria a ser desencadeada através do modernismo brasileiro quase meio século mais tarde na semana de Arte Moderna em São Paulo.

\section{Figura 13}

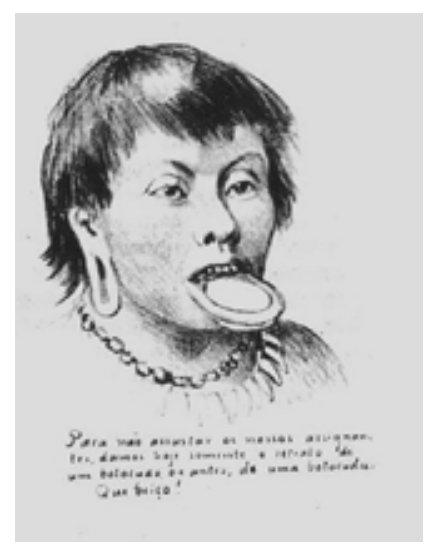

Figura 13: Angelo Agostini, "Uma visita à Exposição Anthropologica", Revista Illustrada (1882). Biblioteca Nacional, Rio de Janeiro. 
No primeiro quadro se apresenta o alter ego de Agostini, um pequeno pierrô, entrando secretamente no museu onde o imperador está inspecionando algumas olarias antropomórficas oferecidas por Netto, que aparece como um verdureiro elogiando a sua mercadoria. A cena vem acompanhada pela frase: "É provável que S. M. tenha feito algumas consideraçóes sobre a religião do Estado" (Angelo Agostini, citado em Schwarcz, 1993: 76-77). No quadro seguinte, o pierrô aparece observando atenciosamente uma roseta de lanças e bastões que, sugere ele, são muito mais esplendorosos do que o colete do imperador: por que não adicionar à capa tucana imperial um cocar e uma saia como as que estão exibidas na exposição, o que faria do imperador um esplêndido cacique? A segunda parte da história está inspirada no quadro da mulher botocuda pintado por Villares. Na cópia deste quadro, feita por Agostini, o autor imagina o encontro amoroso de um casal nativo com os seus lábios cerimonialmente estendidos, dispositivo muito prático na hora dos banquetes canibalistas, como ressalta o cartunista. Ao contrário de Villares, Agostini utiliza o corpo grotesco do outro organizado ao redor da boca devoradora, não enquanto local de interdição que se adianta à empatia romântica (e, desta forma, a qualquer representação que não esteja signada pela afirmação da sua própria impossibilidade), mas enquanto espaço de carnavalização das narrativas de origem, adiantadas pelo indianismo e também pela antropologia. Agostini, em outras palavras, desrespeita a proibição que Villares havia expressado através da boca monstruosa que sobrecodificava o corpo erótico do indianismo, apresentando-o enquanto um corpo "dentado", o impenetrável corpo da primitividade, e o reintroduz numa farsa da época de ouro romântica, completa com o seu próprio Cupido. Na realidade, o quadrinho final onde observamos Netto puxando pelo lábio um índio botocudo, ao tentar prevenir sua fuga do local da exposição, poderia ser interpretada enquanto uma ironia autoreflexiva sobre essa violação da interdição fundamental da exposição, em relação à tomada irônica do anacronismo a qual Netto tentava evitar de maneira vigorosa e desesperada. A boca grotesca, deste modo, representa o espaço onde o realismo científico encarnava a lacuna insuperável entre o índio virtuoso e desejável da fantasia novelística e a alteridade irrepresentável da vida nua cuja humanidade podia ser afirmada apenas de maneira negativa. A história de Agostini, porém, é o lugar onde essa boca expõe a 
sua verdadeira ameaça: a justaposição. Da mesma forma que o caciqueimperador, cuja opção de tornar-se nativo como prova de sua brasilidade ironiza a viagem ritual prescrita por Netto, a botocuda que transgride a interdição oral e regride pelo romance indianista ridiculariza as pretensões de verdade científica das novas representaçooes do Outro, sustentadas pela sua separação enfática da tradição narrativa. A boca grotesca, na história de Agostini, reaparece enquanto local de desarticulação das regulaçóes e demarcações discursivas pelas quais a ciência tinha feito do índio o seu objeto de estudo. Ela inverte, através da imagem em que o pierrô é ameaçado pela ingestão canibalista, as relações de tamanho e objetificação implícitas na ordem visual do museu, que é revelada no quadrinho final enquanto pura antropofagia: a devoração da vida nua pela "curiosidade" que se alimenta dos seus restos.

\section{Bibliografia}

AGAMBEN, Giorgio. 1998. Homo Sacer: Sovereign Power and Bare Life. Stanford: Stanford University Press.

AZEVEDO, Fernando de. 1994. "A antropologia e a sociologia no Brasil”, id. (ed.), As ciências no Brasil, Rio de Janeiro: Ed. UFRJ.

BARBOSA RODRIGUES, João. 1882. Catálogo dos objectos expostos na Exposição Anthropológica do Rio de Janeiro. Rio de Janeiro: Typographia Nacional.

BARTHES, Roland. 1980. La chambre claire. Note sur la photographie. Paris: Gallimard/Seuil.

BENJAMIN, Walter. 1983. "Der Sammler (Konvolut H) ", id., Das PassagenWerk, Erster Band, ed. Rolf Tiedemann, Frankfurt a. M., Suhrkamp.

BARBUY, Heloisa. 1996. "O Brasil vai a Paris em 1889: um lugar na Exposição Universal”, Anais do Museu Paulista, Nova Série, 4: 211-241.

BOSI, Alfredo. 1992. "Um mito sacrifical: o indianismo de Alencar", id., Dialética da colonização, São Paulo: Companhia das Letras.

BROOKSHAW, David. 1988. Paradise Betrayed: Brazilian Literature of the Indian. Amsterdam: CEDLA.

CAMPOFIORITO, Quirino. 1983. História da pintura brasileira no século XIX. Rio de Janeiro: Ed. Pinakotheke. 
CASTRO FARIA, Luiz de. 1949. "As exposições de antropologia e arqueologia do Museu Nacional", Publicaçôes avulsas do Museu Nacional 4.

—. 1993. Antropologia; espetáculo e excelência, Rio de Janeiro: Ed. UFRJ/Fabian. CLIFFORD, James. 1985. "Objects and Selves: an Afterword”, in: G. W. Stocking, Jr. (ed.), Objects and Others. Essays on Museums and Material Culture. Madison: Wisconsin UP.

CUNHA, Manuela Carneiro da. 1986. Antropologia do Brasil. Mito, história, etnicidade. São Paulo: Brasiliense.

CUNHA, Manuela Carneiro da (ed.) 1998. História dos indios no Brasil, São Paulo, Companhia das Letras.

DRIVER, Felix. 2001. Geography Militant: Cultures of Exploration and Empire, Oxford: Blackwell.

DUARTE, Abelardo. 1950. Ladislau Netto (1838-1894). Maceió: Imprensa Oficial. EDWARDS, Elizabeth. 2001. Raw Histories. Photographs, Anthropology, and the Museum. Oxford, New York: Berg.

GAGLIARDI, J. M. 1989. O indigena e a República. São Paulo: Hucitec / EdUSP. GUIMARAENS, Dinah. 1998. A reinvenção da tradição: icones nacionais de duas Américas. Rio de Janeiro: UFRJ/Museu Nacional.

JACKNIS, Ira. 1985. "Franz Boas and Exhibits: On the Limitations of the Museum Method of Anthropology", in: G. W. Stocking, Jr. (ed.), Objects and Others. Essays on Museums and Material Culture. Madison: Wisconsin UP.

JENKINS, David. 1994. "Object Lessons and Ethnographic Displays: Museum Exhibitions and the Making of American Anthropology", Comparative Studies in Society and History 36: 242-270.

KIRSHENBLATT-GIMBLETT, Barbara. 1991. "Objects of Ethnography", in: I. Karp, S. D. Lavine (eds.), Exhibiting Cultures. The Poetics and Politics of Museum Display. Washington, London: Smithsonian.

Kossoy, Boris. 1980. Origens e expansão da fotografia no Brasil, século XIX. Rio de Janeiro: MEC / FUNARTE.

LACERDA, João Baptista de \& PEIXOTO, José Rodrigues. 1876. "Contribuições para o estudo anthropologico das raças indigenas do Brazil, pelos doutores Lacerda Filho e Rodrigues Peixoto", Archivos do Museu Nacional 1: 47-83.

LACERDA, João Baptista de. 1906. Fastos do Museu Nacional: Recordaçôes históricas e scientificas fundadas em documentos authenticos e informaçôes veridicas, Rio de Janeiro: Imprensa Nacional. 
LADISLAU NETTO. 1870. Investigaçōes históricas e scientificas sobre o Museu Imperial e Nacional, acompanhado de uma breve notícia de suas coleç̧ôes epublicadas por ordem do Ministério de Agricultura. Rio de Janeiro: Instituto Philomathico.

- 1877. Relatório do Museu Nacional, apresentado ao Ilustríssimo Exm. Sr. Conselheiro Tomás José Coelho de Almeida pelo Dr. Ladislau Netto, Diretor Geral do Museu. Rio de Janeiro: Imprensa Nacional.

—. 1882. Guia da Exposição Anthropológica Brasileira realisada pelo Museu Nacional do Rio de Janeiro a 29 de julho de 1882, Rio de Janeiro: Leuzinger.

- - 1885a. Conférence faite au Muséum National en présence de LL. MM. Impériales, par le Dr. Ladislau Netto, Directeur Général du Muséum National de Rio de Janeiro. Rio de Janeiro: Machado \& Cia.

—. 1885b. "Investigações sobre a archeologia brazileira", Archivos do Museu Nacional 6.

- 1889. Le Muséum National de Rio de Janeiro et son influence sur les sciences naturelles du Brésil. Paris: Charles Delagrave.

—. 1890. Museu Nacional: Instruç̧ôes sobre a preparação e remessa das colecçôes que lhe forem destinadas. Rio de Janeiro: Imprensa Nacional.

LOPES, Maria Margaret. 1996. "Viajando pelo mundo dos museus: diferentes olhares no processo de institucionalização das Ciências Naturais nos museus brasileiros", Imaginário 3: 59-78.

—. 1998. O Brasil descobre a pesquisa cientifica. As ciências naturais e os museus. São Paulo: Hucitec.

MICELI, Sérgio. 1996. Imagens negociadas: Retratos da elite brasileira (1920-40). São Paulo: Companhia das Letras.

MONTEIRO, John Manuel. 1996. "As 'raças' indígenas no pensamento brasileiro do Império", em: Marcos Chor Maio e Ricardo Ventura Santos (orgs.), Raça, ciência e sociedade. Rio de Janeiro: Fiocruz / CCBB.

Revista da Exposição Antropológica Brasileira (ed. Mello Morães Filho). 1882. Rio de Janeiro: Imprensa Nacional.

ROMERO, Sylvio. 1888. Ethnographia brazileira: Estudos críticos sobre Couto de Magalhães, Barbosa Rodrigues, Teophilo Braga e Ladislao Netto. Rio de Janeiro: Alves \& Cia.

SAES, Décio. 1985. A formação do Estado burguês no Brasil (1888-1891). Rio de Janeiro: Paz e Terra. 
SALLES, Ricardo. 1996. Nostalgia imperial. A formação da identidade nacional no Brasil do Segundo Reinado. Rio de Janeiro: Topbooks.

SCHWARCZ, Lilia Moritz. 1993. O espetáculo das raças: cientistas, instituiçôes e questão racial no Brasil, 1870-1930. São Paulo: Companhia das Letras.

1998. As barbas do Imperador. D. Pedro II, um monarca nos trópicos. São Paulo: Companhia das Letras.

SCHWARTZMAN, S. 1979. Formação da comunidade cientifica no Brasil, São Paulo: Nacional / Rio de Janeiro: Finep.

SCHWARZ, Roberto. 2000. "A importação do romance e suas contradições em Alencar”, id., Ao vencedor as batatas: forma literária e processo social nos inícios do romance brasileiro. São Paulo: Duas Cidades/Editora 34.

SONTAG, Susan. 1979. On Photography. Harmondsworth: Penguin.

SOUZA LIMA, Antonio Carlos de. 1989. Os museus de história natural e a construção do indigenismo. Rio de Janeiro: Museu Nacional/UFRJ.

TAUSSIG, Michael. 1993. “Maleficium: State Fetishism”, in E. Apter \& W. Pietz (eds.), Fetishism as Cultural Discourse, Itahaca, London: Cornell University Press. TREECE, David. 2000. Exiles, Allies, Rebels: Brazil's Indianist Movement, Indigenist Politics, and the Imperial Nation-State. Westport: Greenwood Press. TURAZZI, Maria Inez. 1995. Poses e trejeitos. A fotografia e as exposiçōes na era do espetáculo (1839-1889). Rio de Janeiro: Rocco.

- 2000. Marc Ferrez. Rio de Janeiro: Cosac \& Naify.

VAN GENNEP, Arnold. 1909. Les rites de passage. Paris: Picard, 1981.

VASQUEZ, Pedro. 2002. A fotografia no Império. Rio de Janeiro: Jorge Zahar.

Traduzido do inglês pelo autor e Aquiles Alencar Brayner

\section{Notas}

${ }^{1}$ Meus agradecimentos a Aquiles Alencar Brayner, Alvaro Fernández Bravo, Florencia Garramuño, Gabriela Nouzeilles, Antônio Carlos de Souza Lima e Roberto Said pelos seus comentários e sugestões durante a pesquisa e escritura deste ensaio.

${ }^{2}$ Como David Treece (2000: 11) sugere, o indianismo "ofereceu uma arena dramática e imaginativa onde estas contradições [as de classe, raça e convicção ideológica] poderiam ser encenadas. A exclusão de grandes setores da sociedade brasileira do poder econômico e político poderia ser identificado com a marginalização histórica e contemporânea das 
comunidades tribais da sociedade nacional." O poema épico inacabado de Gonçalves Dias, Os Timbiras, para citar um exemplo, ainda que se referisse ao passado ameríndio imediatamente antes da chegada dos portugueses, apresentava enquanto pano de fundo os massacres e escravização em massa dos membros desta tribo originária do Maranhão (local de nascimento do poeta) que tinha como objetivo a utilização de áreas indígenas para a expansão de pastos beneficiando os criadores de gado.

${ }^{3}$ Sobre Alencar, ver, em além dos trabalhos de Treece e Brookshaw citados anteriormente, Bosi, 1992: 176-193; e Schwarz, 2000: 33-79.

${ }^{4} \mathrm{O}$ declínio do indianismo na literatura, sob a pressão da nova conceitualização de raça, assumindo uma vertente biológica e evolucionista, e a partir dos novos preceitos estéticos do naturalismo, coincidiu com o seu ápice nas artes visuais e performáticas. O Guarani, a adaptação operística de Carlos Gomes subsidiada pelo Estado, foi estreada no teatro Scala di Milano em março de 1870, sendo amplamente aclamada, para depois estrear no Rio em dezembro do mesmo ano. A adaptação pitoresca de Iracema, produzida por José Maria de Medeiros, foi mostrada pela primeira vez em 1881, representando a figura de uma mulher nua saindo de uma floresta escura observando curiosamente a espada de Martim Soares Moreno enfiada nas areias da praia, numa síntese alegórica à conquista territorial e sexual. Da mesma forma, o corpos mortos de Moema - a moça índia rejeitada do poema Caramuru, de José de Santa Rita Durão, afogada depois de jogar-se ao mar ao tentar seguir o navio que levava Diogo Álvares, o conquistador português, de retorno à sua terra natal - e o corpo de Aymbiré, o último índio Tamoio no poema épico de Magalhães, recebendo os sacramentos funerários do padre Anchieta, aparecem nas pinturas homônimas de Victor Meirelles e Rodolfo Amoedo, produzidas em 1866 e 1883 respectivamente, lavados por praias idílicas, seus corpos formando uma ponte simbólica ou uma plataforma de desembarque que demonstra suas funçôes na narrativa como catalisadores da transformação dos heróis brancos em brasileiros, herdeiros legítimos de seu novo país (Ver Schwarcz, 1998: 144-50).

${ }^{5}$ Algumas amostras de crânios dos Botocudo e dois esqueletos completos haviam sido mandados, em 1875, pelo Museu Nacional Brasileiro a Rudolf Virchow em Berlim e Armand de Quatrefages em Paris. Outros renomados fisiologistas europeus, como Blumenbach e Serres, também receberam restos humanos enviados à Europa por colecionadores brasileiros ou trazidos por cientistas europeus em viagens ao Brasil.

${ }^{6}$ Ver também Schwarcz, 1993: 49-54. De acordo com a sugestão de Felix Driver, a "antropologia" no contexto das novas sociedades, não significava somente um novo paradigma científico, mas também uma nova forma radicalizada da sociabilidade masculina da altaclasse que iria se aparecer nos primórdios do modernismo. Ver Driver, 2001: 96-99.

${ }^{7} \mathrm{O}$ artigo de Ihering "A antropologia do Estado de São Paulo”, que defendia a exterminação dos índios Caingang como um obstáculo ao progresso do interior paulista, foi publicado pela primeira vez na contribuição oficial do estado ao pavilhão brasileiro na Exposição de Louisiana em 1905. Ele foi mais tarde reimpresso tanto na Revista do Museu Paulista quanto no Diário do Estado de São Paulo. A passagem controversa (a qual Ihering negaria mais tarde haver intencionado uma recomendação aberta ao genocídio), aparece no texto da 
seguinte forma: "Os índios do estado de São Paulo não representam um elemento de trabalho e de progresso. Como também nos outros estados do Brasil, não se pode esperar trabalho sério e continuado dos índios civilizados, e como os Caingang são um empecilho para a colonização das regiōes do sertão que habitam, parece que não há outro meio de que se possa lançar mão, senão o seu extermínio [...] É minha convicção de que é devido a essas circunstâncias que o estado de São Paulo é obrigado a introduzir milhares de imigrantes, pois não se pode contar de modo eficaz e seguro com os serviços dessa população indígena, para os trabalhos que a lavoura exige." Um fator significante, contudo, é que mesmo recomendando o aniquilamento dessa vida real, o Museu Paulista contribuiria com a Exposição Nacional de 1908, exatamente com uma exposição de "grupos vivos" das mesmas comunidades indígenas consideradas obsoletas pelo seu diretor. O catálogo da exposição menciona " 3 cabanas rústicas, de índios Caingangs ou Coroados, Cayuás e Chavantes. As primeiras construídas no mato e as dos últimos na base do morro da Urca, numa gruta natural. Em cada uma está uma casa silvícola de tamanho natural com os respectivos utensílios e apetrechos de guerra, pesca e caça.” As fotografias da exposição foram publicadas no Catálogo do estado de São Paulo, editado na ocasião para o evento. Desta forma, a simulação da vida nos povoados indígenas constituía a própria evidência para demonstrar (de maneira negativa) sua aptidão para a sobrevivência. Ver Castro Faria, 1993: 64; Souza Lima, 1989.

${ }^{8}$ Ver Netto, 1870: 250-2; 1877. De fato, um decreto baixado pelo governo imperial em 1876, ano da indicação de Netto como diretor do Museu Nacional (o mesmo posto que ele havia ocupado numa base interina desde 1869), ordenava a criação de um museu arqueológico e etnográfico, sem que no entanto nenhuma medida concreta fosse tomada nem tampouco nenhum fundo oferecido.

9 Sobre o desenvolvimento do 'grupo vivo', ver Jacknis, 1985: 75-111; KirshenblattGimblett, 1992: 400-404.

10 "Todas as questôes de antropologia se resumem, como os senhores o sabem, em dois problemas essenciais. O primeiro tem por objetivo a determinação da gênese humana; o segundo, que se encontra intimamente ligado ao primeiro, consiste na discussão das hipóteses do monogenismo ou do poligenismo, em conexão com as leis da evolução na escala zoológica. [...] A dúvida do pensamento confuso [indicado] pelo famoso to be or not to be, a angústia de um cérebro em luta consigo mesmo no abismo do desconhecido, eis aí o que melhor exprime o estado de espírito e do coração daqueles que se dedicam ao estudo dos povos antigos do nosso continente" (Netto, 1885a: 11-12).

11 "É verdade que desde 1867, inspirado pelo trabalho de Louis Lartet que, naquela época, me incentivara a seguir os estudos comparativos entre a cerâmica dos Celta-ibéricos e a olaria primitiva do Brasil, e me encontrei engajado quase que involuntariamente nos estudos deste gênero. Eu o fazia como simples colecionador de materiais dispersos e não enquanto pesquisador experiente e seguro [do seu trabalho]; eu o fazia, enfim, pelo nome e interesse do Museu Nacional, ajudado pela imprensa, graças a qual aquele estabelecimento poderá, mais cedo ou mais tarde, a prioridade das pesquisas desta espécie no Brasil" (Netto, 1885a: 7). 
12 "Charles Hartt começara a exercer desde então sobre o meu espírito uma justificação suficiente de reservas premeditadas que haviam sido indicadas em relação às questôes etnológicas do nosso continente. Porém, seja pela conseqüência do próprio caráter da natureza humana ou seja por uma outra razão, não me foi possível submeter-me totalmente à maneira tão restrita de ver [a etnologia] conforme muitos etnólogos americanos o fazem. Outro motivo que não me permitia fazê-lo foram os inumeráveis documentos que passaram sob os meus olhos, questionando a razão das suas analogias e de suas admiráveis semelhanças com as antiguidades de outros povos primitivos, senão do velho mundo, pelo menos do nosso continente. Eu não poderia negar estas semelhanças, pois elas saltavam aos olhos..." (Netto, 1885a: 9).

${ }^{13}$ Ver Turazzi, 2000; também Kossoy, 1980; Vasquez, 2002.

${ }^{14}$ Os fotógrafos, assim explica Turazzi, competiam nas exposições nacionais por medalhas tanto na categoria de belas-artes quanto, na de produtos industriais (ao contrário de participarem sob a nova categoria de "arte industrial", como ocorria nas feiras mundiais de Paris).

${ }^{15} \mathrm{O}$ álbum do Brasil, que poderia ser adquirido em conjunto ou em imagens individuais, foi a obra-prima da carreira de Ferrez enquanto fotógrafo. Este álbum foi constantemente editado e reorganizado durante a vida dele. Na versão de 1899, que consistia em 72 impressóes em albumina, as primeiras cinco fotografias eram retratos tirados em estúdio de chefes indígenas, assim como também de homens e mulheres negras da Bahia, um tipo de prólogo visual antes que Ferrez partisse para o seu tema favorito, as vistas urbanas do Rio de Janeiro. O álbum termina com fotografias de viadutos ferroviários e das colheitas de café em São Paulo e Minas Gerais: um vôo espaço-temporal de norte a sul, e de um passado marcado por colonialismo e escravidão até o presente (já capturado numa atmosfera de nostalgia elegíaca) do Império tropical, em direção a um futuro de modernidade agroindustrial representado pelos dois estados do café que detinham na época o poder político da nação.

${ }^{16}$ Uma violência de fato compartida por Ferrez: pelo menos uma das suas fotografias das estátuas de gesso foi mais tarde incluída no seu álbum brasileiro como o "retrato de um chefe indígena”.

\section{Resumo}

A Exposição Antropológica Brasileira, celebrada em 1882 no Museu Nacional do Rio de Janeiro, é analizada aqui como um intento monumental e espetacular de revalorizar a iconografia indianista do Império que na época parecia ter-se tornado redundante. A evidência material da "realidade" indígena exigia uma reavaliação da utilidade do índio como representante da nação moderna: da mesma forma em que o discurso indianista não pode estar reduzido a um parâmetro ideológico singular e univocal, porém, a reinscrição científica da vida e da cultura nativa parecia expressar mensa- 
gens contraditórias, mensagens estas que, disseminadas no nível da esfera pública pela Exposição Antropológica, vieram a se tornar ainda mais diversificadas e complexas. $\mathrm{O}$ espetáculo da ciência que dizia substituir os mitos literários ou artísticos sobre o índio, não obstante retomava as dicotomias tradicionais entre bons e maus selvagens, tupis e tapuias, passado e presente. No presente artigo se tentará traçar o percurso deste campo científico emergente, primeiramente contrapondo os novos discursos sobre "raça" e civilização pré-colombiana presentes na tradição indianista, para oferecer logo uma observação mais atenta sobre o modo em que essas diferentes instâncias operavam no nível de ordem dos objetos expostos. A partir daí será discutida a proliferação das representações visuais de objetos, homens e mulheres indígenas presentes na exposição em pintura, escultura, fotografia e caricatura.

Palavras-chave: antropologia, indianismo, museus, exposições, cultura visual.

\section{Abstract}

The Brazilian Anthropological Exhibition, celebrated in 1882 in Rio de Janeiro's National Museum, is analyzed here as a monumental and spectacular attempt to re-evaluate the indianist iconography of the imperial state, which seemed to have become redundant at the time. The material evidence of indigenous "reality" demanded a reappraisal of the Indian's utility as a symbol of the modern nation. Yet, just as indianist discourse cannot be reduced to a single, univocal ideological stance, scientific reinscriptions of native life and culture sent out contradictory messages, which were further complicated and diversified in the uses that were made of the Anthropological Exhibition in the public sphere of Rio de Janeiro. The spectacle of science that supposedly replaced literary and artistic myths of the Indian, in fact reproduced traditional dichotomies between noble and ignoble savages, tupis and tapuias, past and present. The present article charts the emerging field of anthropology as a symbolic arena for the tensions over the identity and status of self and other to be played out, first by counterposing the new discourses on race and pre-Columbian civilizations to the indianist tradition, and then by looking more closely at how their different stances operated at the level of the order of display. It 
goes on to discuss the proliferation of visual representations of the objects and of the indigenous men and women present at the exhibition in painting, sculpture, photography and caricature

Key Words: anthropology, indianism, museums, exhibitions, visual culture.otas 